Prepared in cooperation with the Lac du Flambeau Band of Lake Superior Chippewa Indians

\title{
A Distributed Temperature Sensing Investigation of Groundwater Discharge to Haskell Lake, Lac du Flambeau Reservation, Wisconsin, Jüly 27-August 1, 2016
}

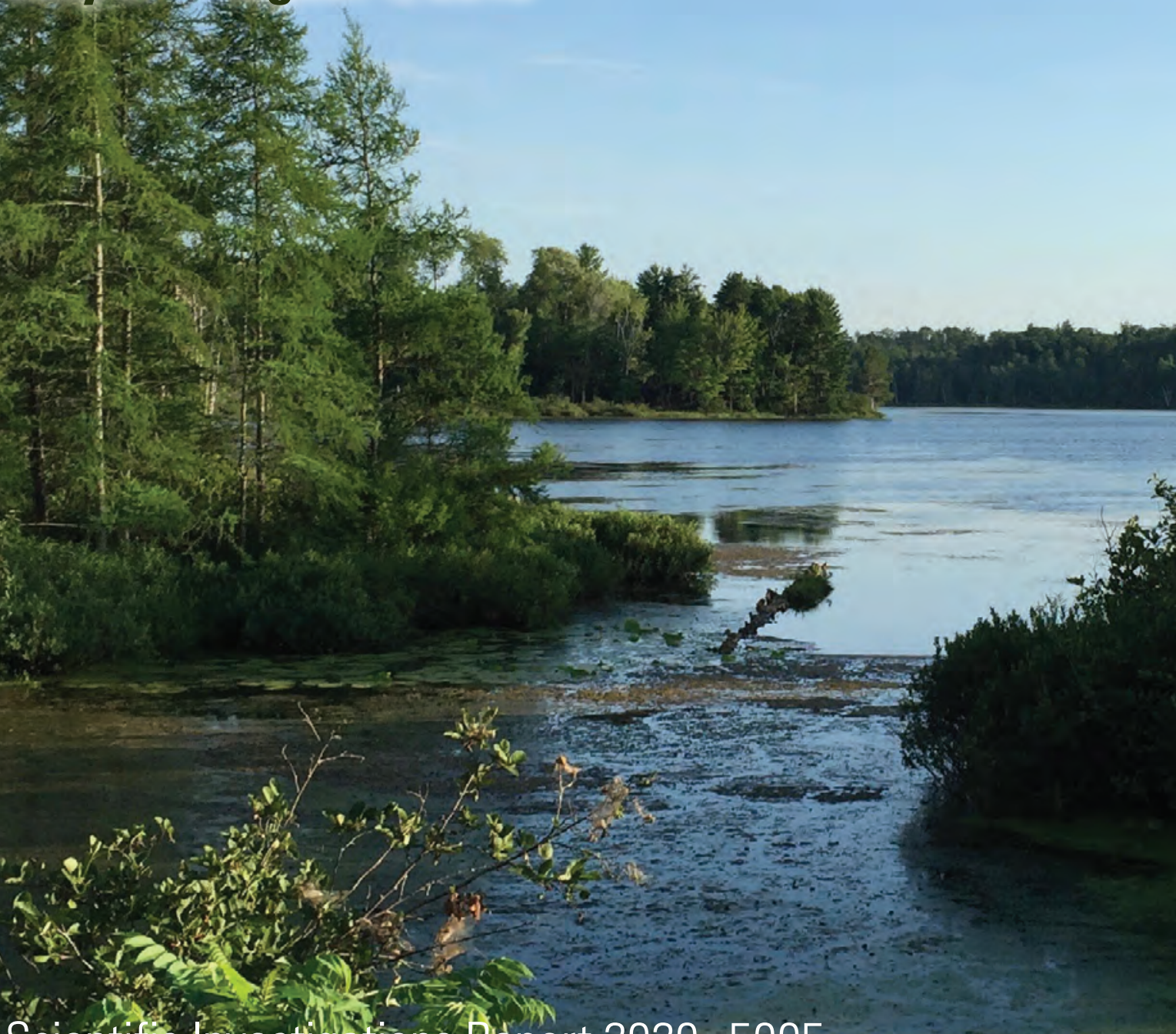

Sctentifo investigations Rejoort 2020-5005

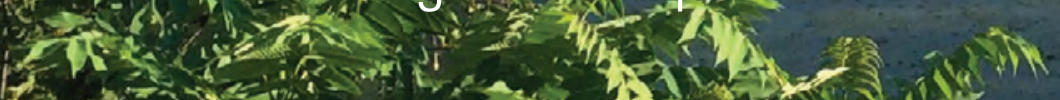

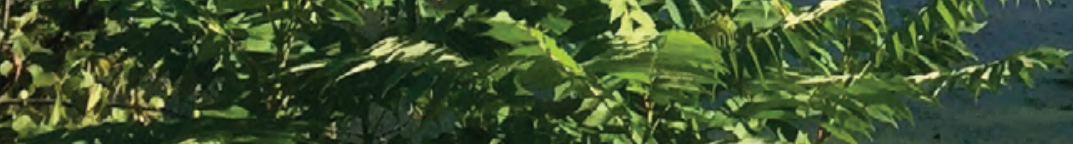

U.S. Department of the Interior: U.S. Geolögical Survey 
Cover. Photograph showing Haskell Lake looking south from the north end of the distributed temperature sensing survey area. Photograph by Andrew Leaf, U.S. Geological Survey.

Back cover Photograph showing the distributed temperature sensing instrument housing. Photograph by Andrew Leaf, U.S. Geological Survey. 


\section{A Distributed Temperature Sensing Investigation of Groundwater Discharge to Haskell Lake, Lac du Flambeau Reservation, Wisconsin, July 27-August 1, 2016}

By Andrew T. Leaf

Prepared in cooperation with the Lac du Flambeau Band of Lake Superior Chippewa Indians

Scientific Investigations Report 2020-5005 


\title{
U.S. Department of the Interior DAVID BERNHARDT, Secretary
}

\author{
U.S. Geological Survey \\ James F. Reilly II, Director
}

\section{U.S. Geological Survey, Reston, Virginia: 2020}

For more information on the USGS - the Federal source for science about the Earth, its natural and living resources, natural hazards, and the environment-visit https://www.usgs.gov or call 1-888-ASK-USGS.

For an overview of USGS information products, including maps, imagery, and publications, visit https://store.usgs.gov.

Any use of trade, firm, or product names is for descriptive purposes only and does not imply endorsement by the U.S. Government.

Although this information product, for the most part, is in the public domain, it also may contain copyrighted materials as noted in the text. Permission to reproduce copyrighted items must be secured from the copyright owner.

Suggested citation:

Leaf, A.T., 2020, A distributed temperature sensing investigation of groundwater discharge to Haskell Lake, Lac du Flambeau Reservation, Wisconsin, July 27-August 1, 2016: U.S. Geological Survey Scientific Investigations Report 2020-5005, 17 p., https://doi.org/10.3133/sir20205005.

Associated data release for this publication:

Leaf, A.T., 2020, Distributed lakebed temperature data, Haskell Lake, Lac du Flambeau Reservation, Wisconsin, July 27-August 1, 2016: U.S. Geological Survey data release, https://doi. org/10.5066/P9X2OHNX.

ISSN 2328-0328 (online) 


\section{Acknowledgments}

Funding was provided by the Lac du Flambeau Band of the Lake Superior Chippewa Indians, through a Water Resources grant from the U.S. Bureau of Indian Affairs and from U.S. Geological Survey Cooperative Water Program funds.

The author acknowledges the following external assistance: Kristen Hanson (Environmental Response Program Coordinator, Lac du Flambeau Band of Lake Superior Chippewa Indians) for being the local project coordinator, Justin Brown (Student Volunteer, University of WisconsinMadison) for field support, Professor Jean Bahr (University of Wisconsin-Madison Department of Geoscience) for providing the fiber optic cable, and David J. Hart (Wisconsin Geological and Natural History Survey) for doing a technical review.

The author also acknowledges the following internal assistance from U.S. Geological Survey colleagues: Brent Olson, Dan Baumann, and Paul Reneau for field support; the Office of Groundwater, Branch of Geophysics for providing the oryx distributed temperature sensing unit; Martin A. Briggs for doing a technical review; Brent Trickett and Valerie Dressler for technical editing; Julia Prokopec for the groundwater specialist review; and Janet M. Carter (Bureau Approving Official) for the Bureau-level review and approval. 



\section{Contents}

Acknowledgements.........................................................................................................................

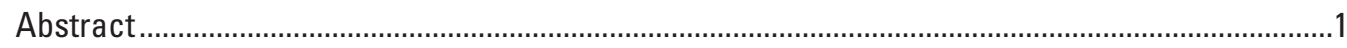

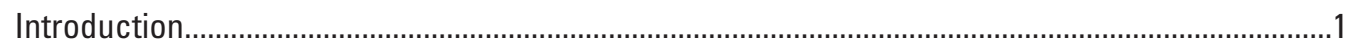

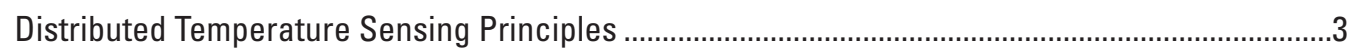

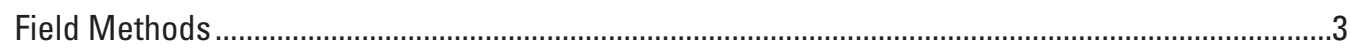

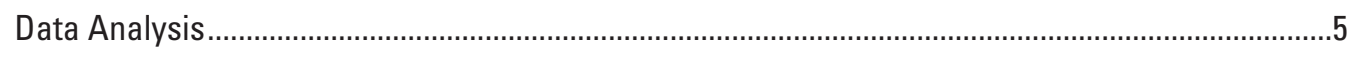

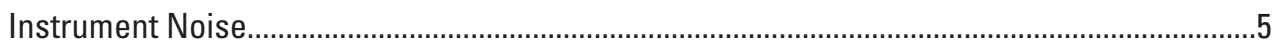

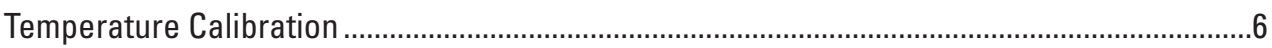

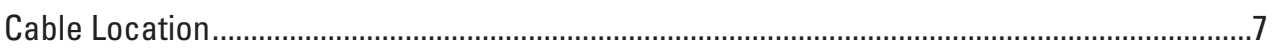

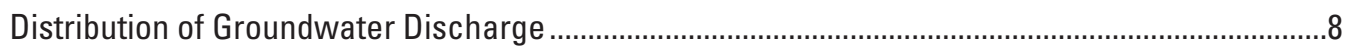

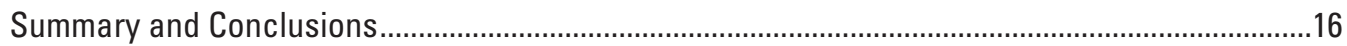

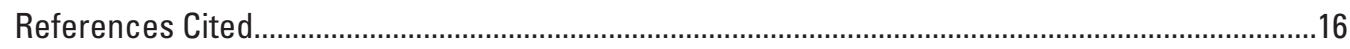

\section{Figures}

1. Map showing Haskell Lake location..............................................................................

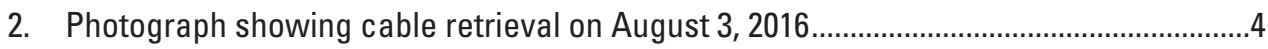

3. Graphs showing comparison of temperatures measured in the calibration baths...........5

4. Graphs showing spurious peaks in the distributed temperature sensing data .................7

5. Graphs showing error in calibrated distributed temperature sensing temperatures

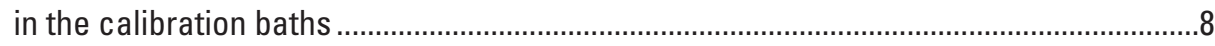

6. Map showing interpreted cable location ....................................................................

7. Graph showing the time-distance image of the complete distributed temperature

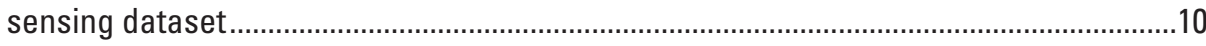

8. Graph showing air temperatures recorded by the section of fiber between the ice bath and lake compared to temperatures recorded at Lakeland Airport ..................11

9. Graphs showing daily temperature range ......................................................................12

10. Graphs showing daily standard deviation in temperatures recorded by the the distributed temperature sensing fiber ...................................................................13

11. Graphs showing daily minimum temperatures recorded by the distributed

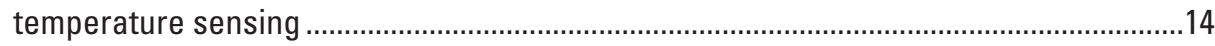

12. Map showing average temperatures between 6 and 7 a.m......................................15 


\section{Conversion Factors}

U.S. customary units to International System of Units

\begin{tabular}{|c|c|c|}
\hline Multiply & By & To obtain \\
\hline \multicolumn{3}{|c|}{ Length } \\
\hline foot $(\mathrm{ft})$ & 0.3048 & meter $(\mathrm{m})$ \\
\hline mile (mi) & 1.609 & kilometer $(\mathrm{km})$ \\
\hline \multicolumn{3}{|c|}{ Area } \\
\hline square mile $\left(\mathrm{mi}^{2}\right)$ & 259.0 & hectare (ha) \\
\hline square mile $\left(\mathrm{mi}^{2}\right)$ & 2.590 & square kilometer $\left(\mathrm{km}^{2}\right)$ \\
\hline acre & 0.404685 & hectare (ha) \\
\hline
\end{tabular}

Temperature in degrees Celsius $\left({ }^{\circ} \mathrm{C}\right)$ may be converted to degrees Fahrenheit $\left({ }^{\circ} \mathrm{F}\right)$ as follows:

$$
{ }^{\circ} \mathrm{F}=\left(1.8 \times{ }^{\circ} \mathrm{C}\right)+32
$$

\section{Datum}

Vertical coordinate information is referenced to the North American Vertical Datum of 1988 (NAVD 88).

Horizontal coordinate information is referenced to the North American Datum of 1983 (NAD 83).

\section{Abbreviations}

DGPS differential global positioning system

DTS distributed temperature sensing

GIS geographic information system

RMSE root mean squared error

RTD resistance temperature detector

USGS U.S. Geological Survey 


\title{
A Distributed Temperature Sensing Investigation of Groundwater Discharge to Haskell Lake, Lac du Flambeau Reservation, Wisconsin, July 27-August 1, 2016
}

\author{
By Andrew T. Leaf
}

\section{Abstract}

Haskell Lake is a shallow, 89-acre drainage lake in the headwaters of the Squirrel River, on the Lac du Flambeau Reservation in northern Wisconsin. Historically, this lake was an important producer of wild rice for the Lac du Flambeau Band of Lake Superior Chippewa Indians (LDF Tribe); but, beginning in the late 1970 s, the rice began to diminish and by the late 1990s, the lake no longer had harvestable stands. Restoring wild rice to Haskell Lake is a long-term priority for the LDF Tribe. A first step towards that effort is the cleanup of a petroleum-contamination plume in the shallow aquifer upgradient of the northern end of the lake. Knowledge of the downgradient extent of the plume and the locations where contaminated water is discharging to the lake is needed to inform cleanup efforts.

A cooperative study between the U.S. Geological Survey and the LDF Tribe was initiated to characterize the distribution of groundwater discharge to Haskell Lake in the areas downgradient of the contamination plume. A fiber optic distributed temperature sensing system was used to monitor temperatures at the sediment-water interface for a 7-day period in July and August 2016. Challenges during the investigation included data storage and power supply limitations, maintenance of calibration baths, accurate location of the cable in space, cable placement in weeds and soft sediment, the confounding effects of solar radiation, and contamination of the data by multiple sources of instrument noise. The problem of instrument noise was overcome by solving the fiber optic distributed temperature sensing calibration equation for two parameters that describe temporal variation in the source laser and the photon detectors that observe the backscatter. Early morning temperatures, when the influence of solar radiation via direct warming of the sediment-water interface is minimized, were used to evaluate groundwater discharge, similar to other studies. The results indicate a persistent, horizontal variation in temperature of as much as 5.5 degrees Celsius across the study area, with cooler temperatures interpreted to indicate spatially discrete preferential groundwater discharge. Results of the study can be used to determine locations for collecting lakebed pore water samples to better define the extent of contamination discharging to the lake.

\section{Introduction}

Haskell Lake is an 89-acre drainage lake in the headwaters of the Squirrel River, on the Lac du Flambeau Reservation in northern Wisconsin (fig. 1). Historically, this lake was an important producer of wild rice for the Lac du Flambeau Band of Lake Superior Chippewa Indians (LDF Tribe); but, beginning in the late 1970s, the rice began to diminish and by the late 1990s, the lake no longer had harvestable stands. Restoring wild rice to Haskell Lake is a long-term priority for the LDF Tribe. A first step towards that effort is the cleanup of a petroleum-contamination plume in the shallow aquifer upgradient of the northern end of the lake. Knowledge of the downgradient extent of the plume and the locations where contaminated water is discharging to the lake is needed to inform cleanup efforts.

The surrounding area is characterized by irregular topography and a nascent drainage network that reflect the recent retreat of the Laurentide Ice sheet only 10,000 years ago. Numerous lakes and wetlands dot the land surface, filling kettle depressions left by the melt out of stagnant ice. Subsurface lithology consists of as much as 280 feet (ft) of glacial deposits; primarily outwash sands and gravels, with intermittent silt-rich debris flow sediments of supraglacial origin; and areally extensive but relatively thin till units that also contain appreciable silt (Attig, 1985). Haskell Lake occupies a kettle depression in collapsed glacial outwash sediments and probably some debris flow deposits (Leaf and Haserodt, 2020). The substrate beneath Haskell Lake is primarily a dark brown, diatomaceous sapropel (about 40-60 percent organic matter) that has a high-water content in the upper $6 \mathrm{ft}$ and ranges in thickness from absent near shore to more than $30 \mathrm{ft}$ thick away from shore. The bottom interface of the sapropel with the underlying hard mineral sediments drops off steeply, making 


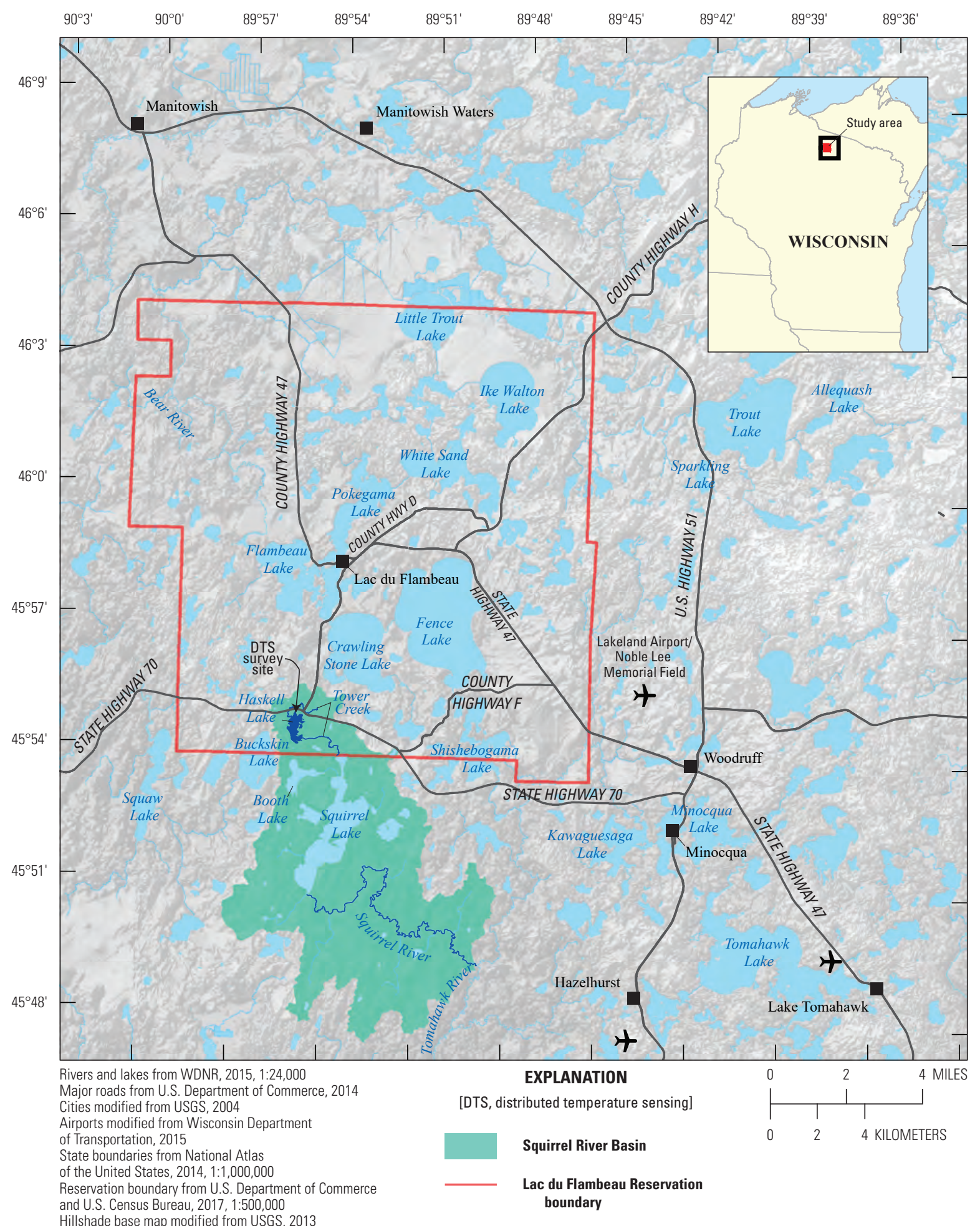

Figure 1. Haskell Lake location (modified from Leaf and Haserodt, 2020).

wading generally infeasible more than a few feet away from shore (Leaf and Haserodt, 2020).

A key challenge in characterizing groundwater-lake interactions in glacial settings is that aquifer heterogeneity can produce spatially preferential discharge patterns that differ substantially from the exponential decay of seepage away from shore predicted for a homogenous aquifer (McBride and Pfannkuch, 1975). For example, Krabbenhoft and Anderson (1986) identified an offshore area of high seepage in a similar setting at nearby Trout Lake (fig. 1), which was caused by a subsurface lens of coarse-grained material intersecting the lake. In another heterogeneous glacial setting in Denmark, 
Sebok and others (2013) observed groundwater discharge originating from the opposite side of a lake, as well as large variations in groundwater seepage rate at scales of less than 1 meter, and seasonal changes in discharge patterns driven by changes in head gradients.

In Haskell Lake, the locations and magnitude of groundwater discharge downgradient of the petroleumcontamination plume are of interest for locating pore water sampling to define the plume extent and contaminant flux to the lake. However, most available field techniques for characterizing groundwater discharge to surface water (for example, seepage meters and vertical temperature profilers) only observe a single point along the interface, making collection of data from many points prohibitively labor intensive (Rosenberry and others, 2008; appendix 6 in Leaf and Haserodt, 2020).

Fiber optic distributed temperature sensing (DTS) allows for the continuous observation of temperature at the meter scale along a fiber optic cable, at regular intervals through time. Temperatures near the sediment-water interface can be used to identify groundwater discharge to surface water when a thermal contrast exists between groundwater and surface water (Conant, 2004) or when discharging groundwater reduces daily variations in temperature (Lowry and others, 2007). DTS has been used to study groundwater and surfacewater interactions for more than a decade; one of the earliest applications investigated groundwater discharge to nearby Allequash Creek in central Vilas County, Wisconsin (near Allequash Lake in fig. 1; Lowry and others, 2007).

A cooperative study between the U.S. Geological Survey (USGS) and the LDF Tribe was initiated to investigate the distribution of groundwater discharge to Haskell Lake in the areas downgradient of the petroleum-contamination plume. DTS was used to monitor temperatures at the sediment-water interface between July 27 and August 3, 2016, when the thermal contrast between the lake and groundwater was close to its annual maximum. This report documents the DTS study, including the field deployment, data processing methods, and key findings.

\section{Distributed Temperature Sensing Principles}

In DTS, a laser pulse is emitted down a fiber optic cable, and the backscattered light is monitored through time. Inelastic collisions between the emitted photons and crystalline structures in the fiber produce red-shifted (Stokes) and blueshifted (anti-Stokes) components in the backscatter; the ratio of the Stokes and anti-Stokes amplitudes varies as a function of temperature (Hausner and others, 2011). The temperature at a given point $(z)$ and time $(t)$ along the cable is determined by using an equation from van de Giesen and others (2012) as follows:

$$
T(z, t)=\frac{\gamma}{\ln \left(\frac{P_{s}(z, t)}{P_{a S}(z, t)}\right)+C(t)-\int_{0}^{z} \Delta a\left(z^{\prime}\right) d z^{\prime}}
$$

where

$$
\begin{array}{cl}
\gamma & \text { is } h \Omega / k ; \\
h & \text { is Planck's constant; } \\
k & \text { is Boltzmann's constant; } \\
\Omega & \text { is the frequency shift between the } \\
& \text { backscattered Stokes radiation and incident } \\
\frac{P_{s}}{P_{a S}} & \text { laser; } \\
C \quad & \text { is the Stokes/anti-Stokes ratio; } \\
& \text { accounts for the relative efficiencies of } \\
& \text { the Stokes and anti-Stokes measurements } \\
& \text { made by the instrument, which can be } \\
& \text { affected by operating conditions such as } \\
& \text { instrument temperature, humidity, and } \\
& \text { fluctuations in the power supply; and } \\
\text { is the differential attenuation of the Stokes/ } & \text { anti-Stokes backscatter along the cable. }
\end{array}
$$

Equation 1 indicates that to determine temperature, the differential attenuation and parameters $C$ and $\gamma$ must be accounted for. In theory the parameter $\Omega$ is constant for a given DTS laser system. However, in practice $\Omega$ has been known to be affected by instrument temperature and power supply (Hausner and others, 2011). The values of $C$ and $\gamma$ can be solved for using independent measurements of temperature at different points along the cable; the differential attenuation term can be directly computed using DTS measurements from both ends of the fiber. Previously documented DTS calibrations have included $\gamma$ as a time-varying parameter (Hausner and others, 2011) or assumed a single, fixed value (van de Giesen and others, 2012; McDaniel and others, 2018), with the latter two studies reporting little effect on calibration quality. Both the variable and single-value $\gamma$ approaches to calibration were tested in the study. A more thorough description of the DTS method and applications to hydrology can be found in Tyler and others (2009). Detailed descriptions of methods for estimating the $C, \gamma$, and $\Delta \alpha$ terms can be found in Hausner and others (2011) and van de Giesen and others (2012).

\section{Field Methods}

A 2004-model Oryx DTS interrogator (Sensornet Ltd) was obtained from the USGS Office of Groundwater Branch of Geophysics, and a 1,130-meter (3,700-ft), 2008-model BRUsteel armored cable (Brugg Cables) with two optical fibers, each terminated by a connection port on either end (four ports total) was provided by Professor Jean Bahr (University of Wisconsin Madison Department of Geoscience). The cable 
was doubled back on itself (duplexed), so that the four connection ports were collocated (all going into the DTS interrogator), with the cable midpoint making up the opposite (distal) end. This duplexed configuration left $1,850 \mathrm{ft}$ of doubled cable available for measurements, allowing for locations along the doubled cable to be measured from two different directions and differential attenuation to be directly calculated.

Approximately $1,400 \mathrm{ft}$ of the armored cable were deployed on July 27,2016 , using a small rowboat. The cable was allowed to settle into the soft substrate under its own weight. No additional weighting was used because of concern that the cable might sink unevenly into the soft sediments near the locations of any weights. Observation of the cable on retrieval indicated that it had mostly settled evenly into the top few inches of sapropel sediment below the sediment-water interface. In a few areas of dense aquatic vegetation, however, downward trends in temperatures throughout the deployment indicated that the cable may have initially rested on submerged vegetation, then slowly sunk towards the sedimentwater interface.

Distances along the cable were marked every $20 \mathrm{ft}$. Location of the cable was recorded on retrieval of the cable (August 3,2016 ) by mounting a differential global positioning system (DGPS) receiver, sampling at a rate of 1 hertz on the stern of the rowboat (fig. 2), and then noting the times of retrieval for distances along the cable at an interval of approximately $100 \mathrm{ft}$ or less.

Two calibration baths, each containing approximately $66 \mathrm{ft}$ (20 meters) of coiled fiber optic cable placed in insulated coolers filled with water, were installed in a shaded location on shore near the DTS interrogator unit. One bath consisted of an ice-water mixture that was maintained throughout the deployment; the second bath was left at ambient temperature. In both baths, the cable coils were kept off the bottoms of the

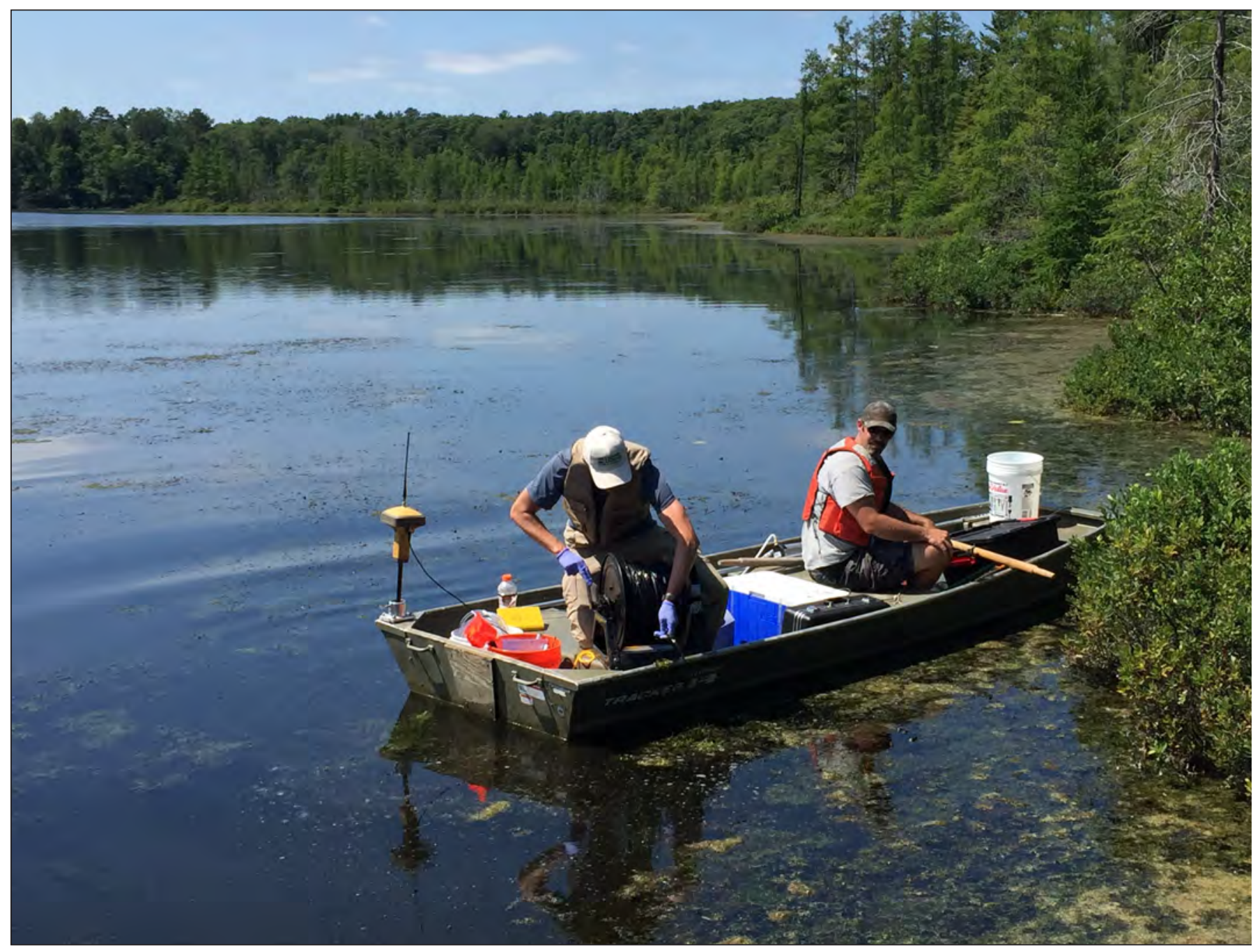

Figure 2. Cable retrieval on August 3, 2016. Photograph by Bob Egan, U.S. Environmental Protection Agency, used with permission. 
coolers using foam tubing, and coiled tight enough to minimize contact with the cooler sides. External reference resistance temperature detector (RTD) thermometers connected to the Oryx unit, and independent temperature loggers (Solinst Leveloggers; accuracy of 0.1 degree Celsius $\left[{ }^{\circ} \mathrm{C}\right]$; resolution of $0.1{ }^{\circ} \mathrm{C}$ ) were both attached to the fiber optic cable coils using zip ties, and set to record temperature every 5 minutes. The accuracy and precision of both Leveloggers was verified prior to the DTS deployment, using an ice bath assumed to be about $0.07{ }^{\circ} \mathrm{C}$ (Tyler and others, 2009). Continuous circulation was maintained in each cooler with two small, submersible electric pumps.

The Oryx interrogator unit was installed on shore in weatherproof housing similar to that used for USGS streamgages. Power for the Oryx unit and cooler circulation pumps was provided by two 100-watt solar panels and a 100-amp-hour battery. Following a rough field calibration using the Oryx control software, the instrument was set to acquire temperature profile measurements every 30 seconds and average (stack) every 10 measurements to improve precision, resulting in a 5-minute measurement interval. A spatial sampling interval of 1.01 meters was used (each data point represents an average for that length of cable). Measurements were made in both fibers, in the forward and reverse directions, resulting in a 20-minute cycle between measurements in the same channel and direction. USGS staff visited the site every 2 days to download collected data from the Oryx to a laptop and refresh the ice bath.

\section{Data Analysis}

The temperature data collected for this study are available in a companion data release (Leaf, 2020). The field data were processed to estimate temperatures along the cable and the physical location of the cable in space. This section of the report describes analysis of instrument noise, temperature calibration, and cable location, which presented challenges during this study.

\section{Instrument Noise}

Inspection of the apparent temperatures recorded by the Oryx control software (Sensornet, 2007) revealed several issues with the field calibration. A negative bias in the apparent temperatures of approximately $7^{\circ} \mathrm{C}$ appeared to be caused by the field calibration being completed before the temperature coil in the ice bath had equilibrated (the cable in the ice bath was actually warmer than $0{ }^{\circ} \mathrm{C}$ but was incorrectly assumed to be at $0^{\circ} \mathrm{C}$ ). Further inspection revealed instrument noise of several degrees Celsius, which seems to be present in the temperatures reported for the fiber optic cable and the reference RTD thermometers connected to the Oryx instrument.

Figure 3 compares apparent temperatures for the calibration baths recorded by the DTS fiber, reference (RTD)

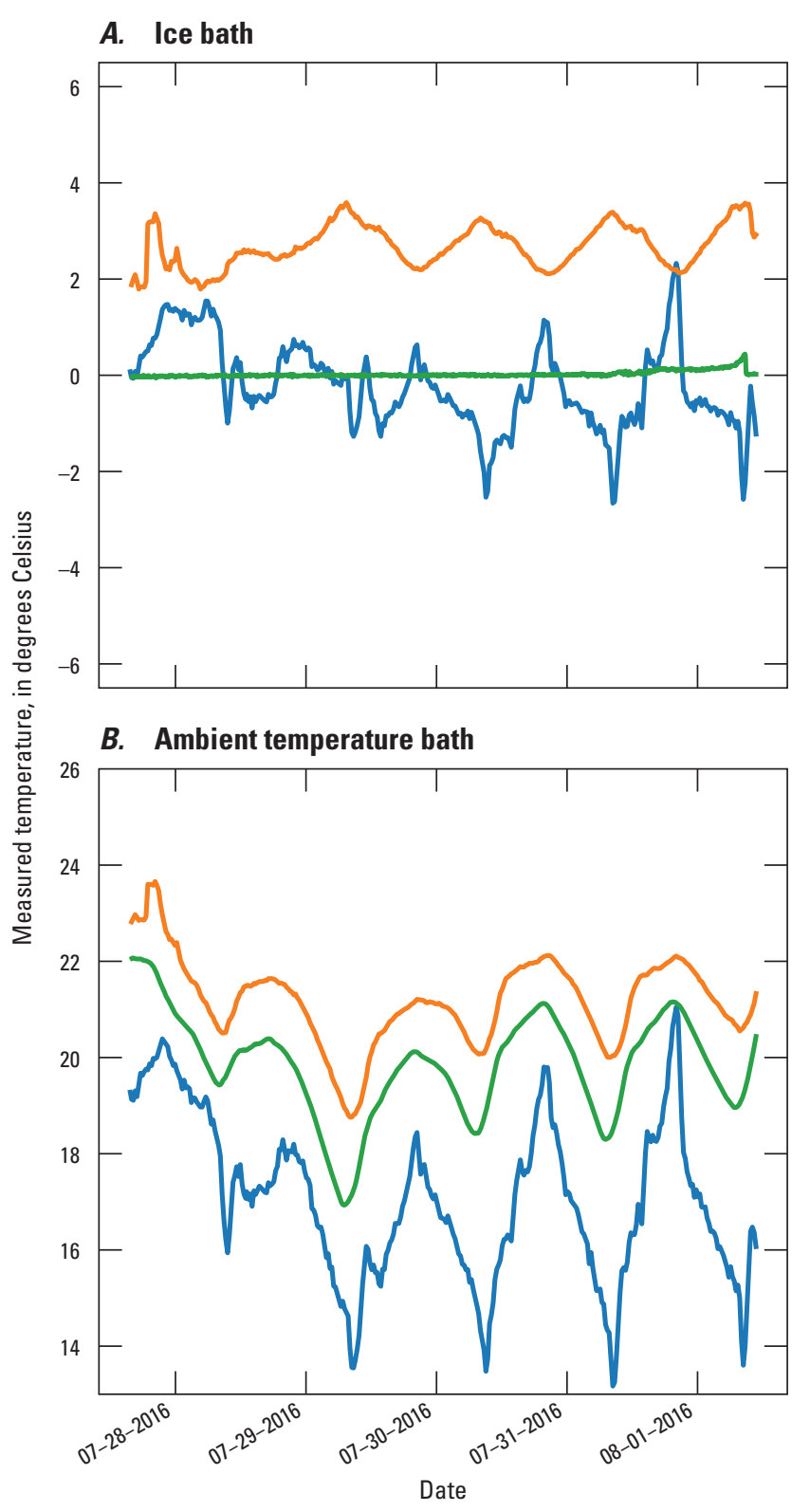

EXPLANATION

[DTS, distributed temperature sensing; RTD, resistance temperature detector]

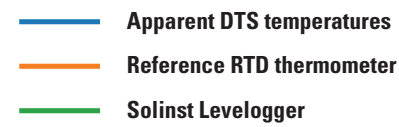

Figure 3. Comparison of temperatures measured in the calibration baths. $A$, ice bath and $B$, ambient temperature bath. The apparent distributed temperature sensing temperatures are a spatial average of the coil immersed in the calibration bath. The Solinst Levelogger temperatures are assumed to be accurate to within plus or minus 0.1 degree Celsius. The apparent distributed temperature sensing temperatures recorded by the Oryx software, and the reference resistance temperature detector thermometers show instrument noise of several degrees Celsius or more, possibly related to changes in the instrument power supply or operating temperature, or both. 
thermometers, and Leveloggers. The instrument noise is nonrandom and appears to follow a diurnal pattern. Increasing spikes in the apparent fiber temperatures towards the end of the deployment are most likely explained by diurnal variations in the ambient temperature experienced by the Oryx unit, which could affect the $C$ and $\gamma$ parameters. The weather during the deployment was initially cloudy, with increasing sun and eventually clear skies by July 31,2016, consistent with increasingly severe positive and negative deviations in the apparent temperatures, which may have been additionally enhanced by direct solar radiation on the instrument enclosure. The cause of the noise pattern in the reference RTD thermometers, which is diurnal but offset in phase between the two calibration baths, is unclear. The noise in the reference RTD thermometers precludes calibration of the DTS data with the Oryx software and underscores the importance of external reference temperatures that are completely independent of the DTS instrument.

\section{Temperature Calibration}

Two approaches to estimating the $C$ and $\gamma$ parameters (to get DTS temperatures) were investigated. The first approach involved optimization of $C$ and $\gamma$ to minimize the squared error between the DTS calibration bath temperatures and external temperature measurements made by the Leveloggers (for example, van de Giesen and others, 2012). The second approach involved explicitly solving equation 1 for $C$ and $\gamma$ simultaneously, using the DTS temperatures in both calibration baths (similar to Hausner and others, 2011). All computations were done in a Jupyter Notebook (http://jupyter.org/) available in the companion data release (Leaf, 2020).

In both approaches, differential attenuation for a section of fiber was determined by comparing DTS measurements taken from opposite ends (forward and reverse) as follows:

$$
\int_{z}^{z+\Delta z} \Delta a\left(z^{\prime}\right) d z^{\prime}=\frac{\ln \left(\frac{P_{S}(z+\Delta z)}{P_{a S}(z+\Delta z)}\right)_{\text {forward }}-\ln \left(\frac{P_{s}(z)}{P_{a S}(z)}\right)_{\text {forward }}+\ln \left(\frac{P_{s}(z)}{P_{a S}(z)}\right)_{\text {reverse }}-\ln \left(\frac{P_{S}(z+\Delta z)}{P_{a S}(z+\Delta z)}\right)_{\text {reverse }}}{2}
$$

Equation 2 can then be summed for successive increments of cable to get the cumulative effect of differential attenuation between a measurement point and the DTS transmitter/receiver (the differential attenuation term in eq. 1).

Because the DTS cable was duplexed, four sections of cable were available for calibration (two instances of each bath). In the optimization approach, the sum of residuals across all four cable sections in the baths was minimized using the minimize function in SciPy (Jones and others, 2001). Optimization was completed with $C$ and $\gamma$ together and $C$ only, with $\gamma$ fixed at the mean value from the combined optimization.

The explicit calibration approach involved rearranging equation 3 in Hausner and others (2011), substituting the computed differential attenuation terms (eq. 2) at the locations of the calibration baths (where temperatures $T_{1}$ and $T_{2}$ were independently measured) as follows:

$$
\left[\begin{array}{cc}
1 & -T_{1} \\
1 & -T_{2}
\end{array}\right]\left[\begin{array}{l}
\gamma \\
C
\end{array}\right]=\left[\begin{array}{ll}
T_{1} & \left(\ln \frac{P_{a}\left(z_{1}\right)}{P_{a S}\left(z_{1}\right)}-\int_{0}^{z_{1}} \Delta a\left(z^{\prime}\right) d z^{\prime}\right) \\
T_{2} & \left(\ln \frac{P_{a}\left(z_{2}\right)}{P_{a S}\left(z_{2}\right)}\right)-\int_{0}^{z_{2}} \Delta a\left(z^{\prime}\right) d z^{\prime}
\end{array}\right]
$$

In this case, only the near cable section in the ice bath and distal cable section in the ambient bath were used; the remaining two cable sections were used for validation.

$C$ and $\gamma$ (when not fixed) were determined for each measurement time, and temperatures along the cable were computed using equation 1 . Although the results were generally acceptable for the goals of the study (detecting groundwater-related anomalies on the order of a few degrees Celsius), none of the calibration methods were able to completely remove spurious peaks in the temperature data that are on the order of a few tenths of a degree Celsius. Although optimization of $C$ and $\gamma$ together resulted in the lowest error at the calibration baths, optimization of just $C$ was ultimately selected because it appeared to reduce the magnitude of the peaks somewhat, which are visible as horizontal bands in the time-distance plane (fig. $4 A$ ). The explicit calculation method produced similar overall results to optimization of $C$ and $\gamma$ (fig. $4 B$ ), but resulted in a less favorable balance of error among the calibration coils, because only two of the four coils were used in the parameter estimation (error was negligible in the coils used and somewhat higher than the combined optimization in the remaining two baths). 

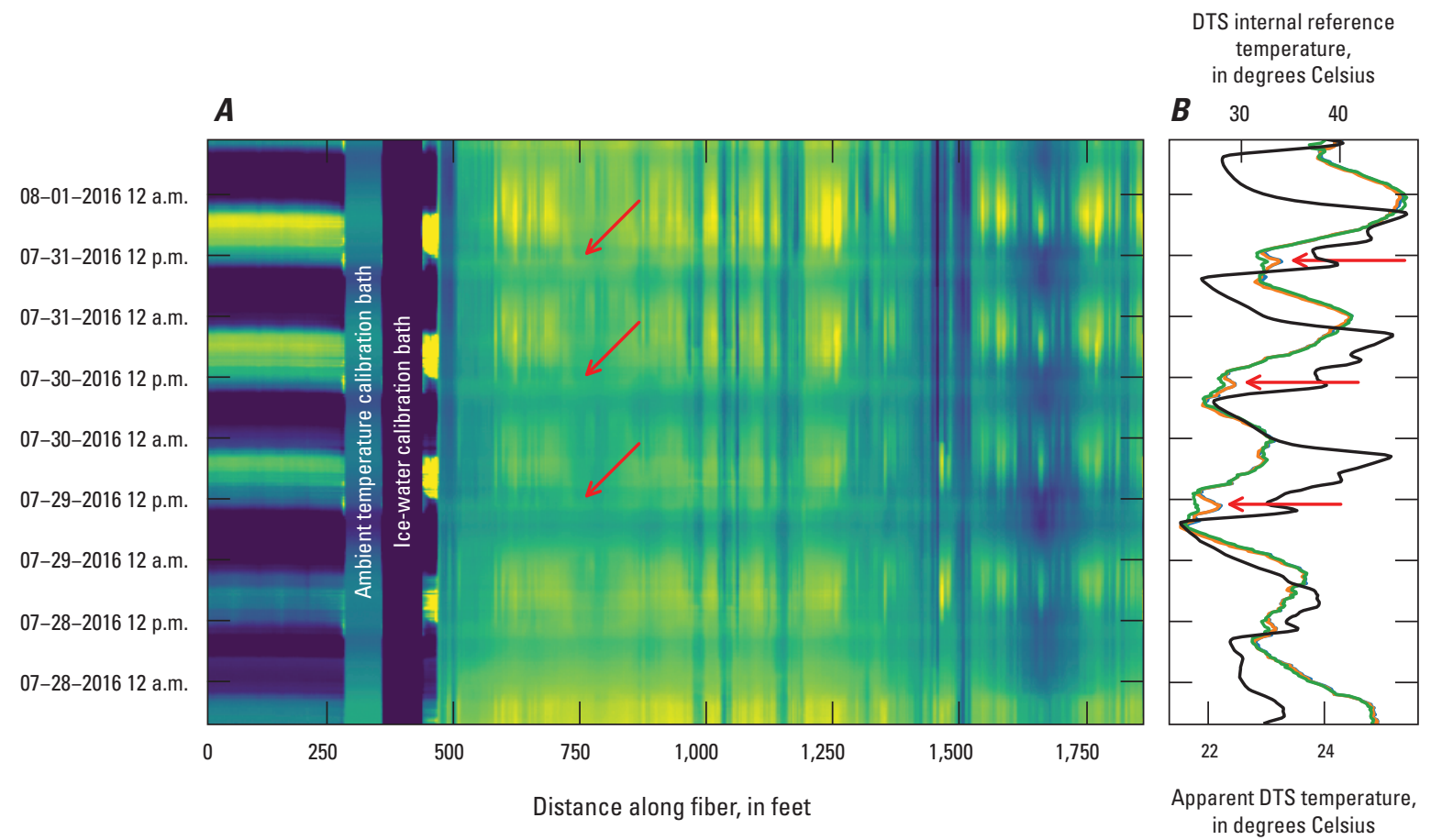

EXPLANATION

[DTS, distributed temperature sensing]

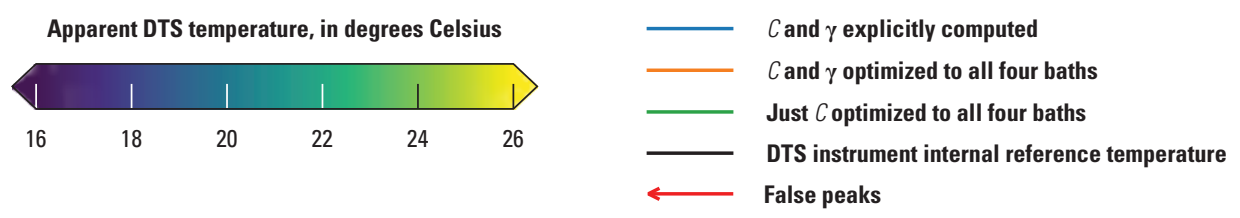

Figure 4. Spurious peaks in the distributed temperature sensing data, $A$, as seen in the timedistance plane and $B$, with individual temperature traces at the 600 -foot cable distance compared to the internal reference temperature of the distributed temperature sensing instrument. The peaks are visible as horizontal bands across the time-distance image $(A)$, which shows the dataset as calibrated by optimizing $C$ and $\gamma$. The peaks are likely an artifact of the instrument because they are visible across the entire dataset and correspond temporally with spikes in instrument temperature $(B)$. Optimization of just the $C$ parameter was selected as the calibration method because it appears to reduce the magnitude of the peaks somewhat ( $B$ and fig. 7 ).

The cause of the peaks is unclear; however, they may be related to sun shining on instrument housing and solar panel assembly during the same period each morning (through a gap in the tree canopy). The peaks all occur around 11 a.m. and coincide with spikes in the internal reference temperature of the DTS instrument.

Figure 5 shows error in the spatial mean of the calibrated DTS temperatures for the calibration baths. Root mean squared error (RMSE) of the DTS temperatures varies up to approximately plus or minus $0.3^{\circ} \mathrm{C}$ through time, with average RMSE values ranging from 0.07 to $0.10^{\circ} \mathrm{C}$ for the four coils. The pattern in the noise is nonrandom, with peaks corresponding to the false peaks observed in the temperature data, except that the anomalies are positive in the ice baths and negative in the ambient temperature baths. Adjustment of $\gamma$ in addition to $C$ reduces these peaks in the calibration baths but increases the magnitude of false peaks elsewhere in the dataset (figs. $4 A-B$ ).

\section{Cable Location}

Accurate location of the cable in space was also challenging because the boat stern, where the DGPS receiver was located, did not always coincide with the cable during retrieval. Obstacles such as logs and emergent vegetation made control of boat position difficult. This issue was partially addressed by recording the retrieval times of known distances along the cable when the distance markings were close to 
A. Near instance of ice bath

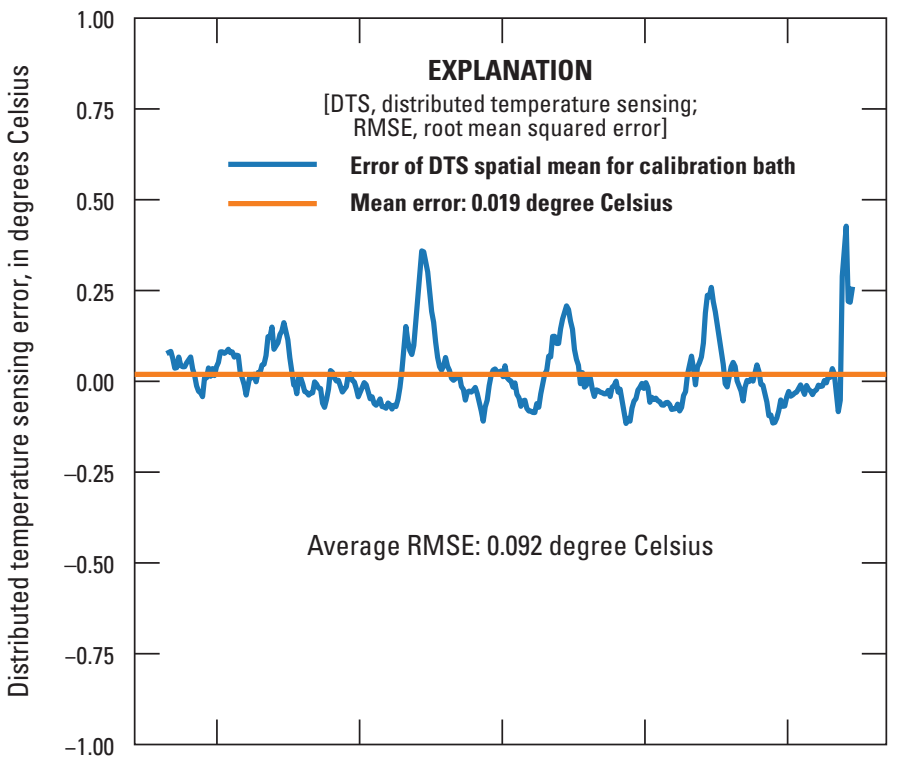

C. Near instance of ambient bath

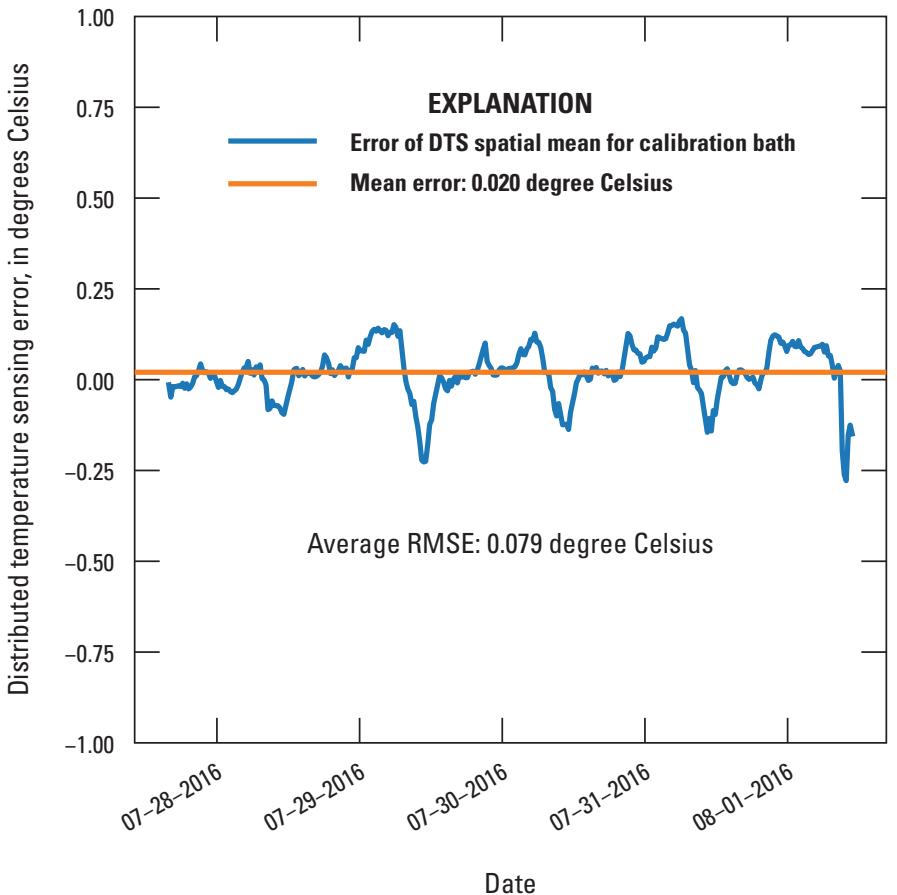

B. Far instance of ice bath

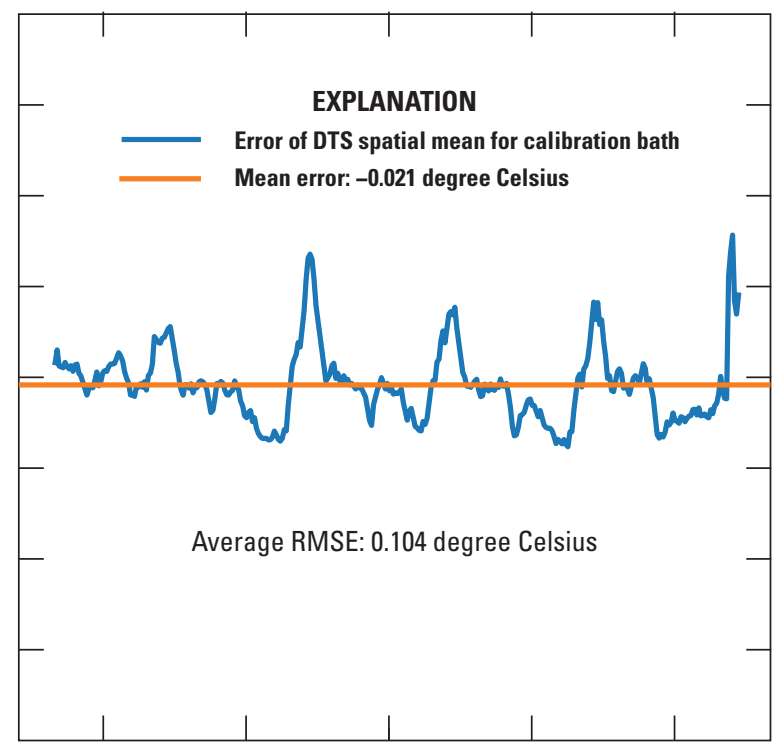

D. Far instance of ambient bath

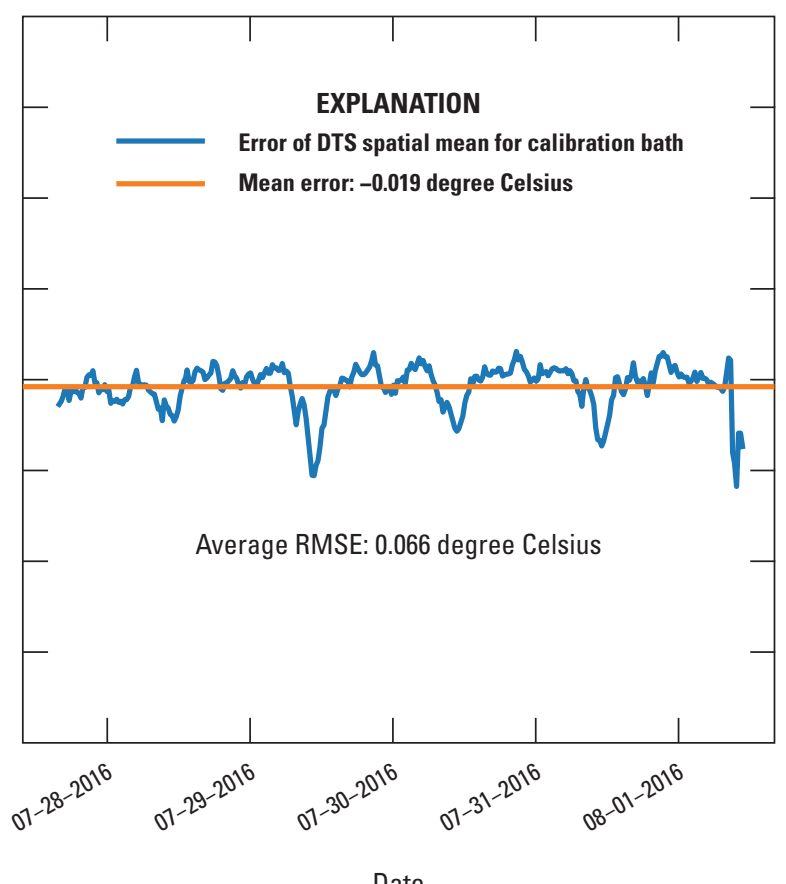

Figure 5. Error in calibrated temperatures. $A$, near instance of ice bath; $B$, far instance of ice bath; $C$, near instance of ambient bath; and $D$, far instance of ambient bath. The error is defined as the difference between the spatial mean of distributed temperature sensing temperatures and the external reference temperature recorded by the Levelogger.

the DGPS receiver. The position of the cable was ultimately interpreted by hand in a geographic information system (GIS) environment, through comparison of the recorded boat track and locations of known cable distances with satellite imagery and field notes (fig. 6).

\section{Distribution of Groundwater Discharge}

A time-distance image of the complete, calibrated DTS dataset is shown in figure 7. Compared to figure $4 A$, which shows the dataset calibrated using $C$ and $\gamma$, a subtle, but noticeable reduction in horizontal banding across the 


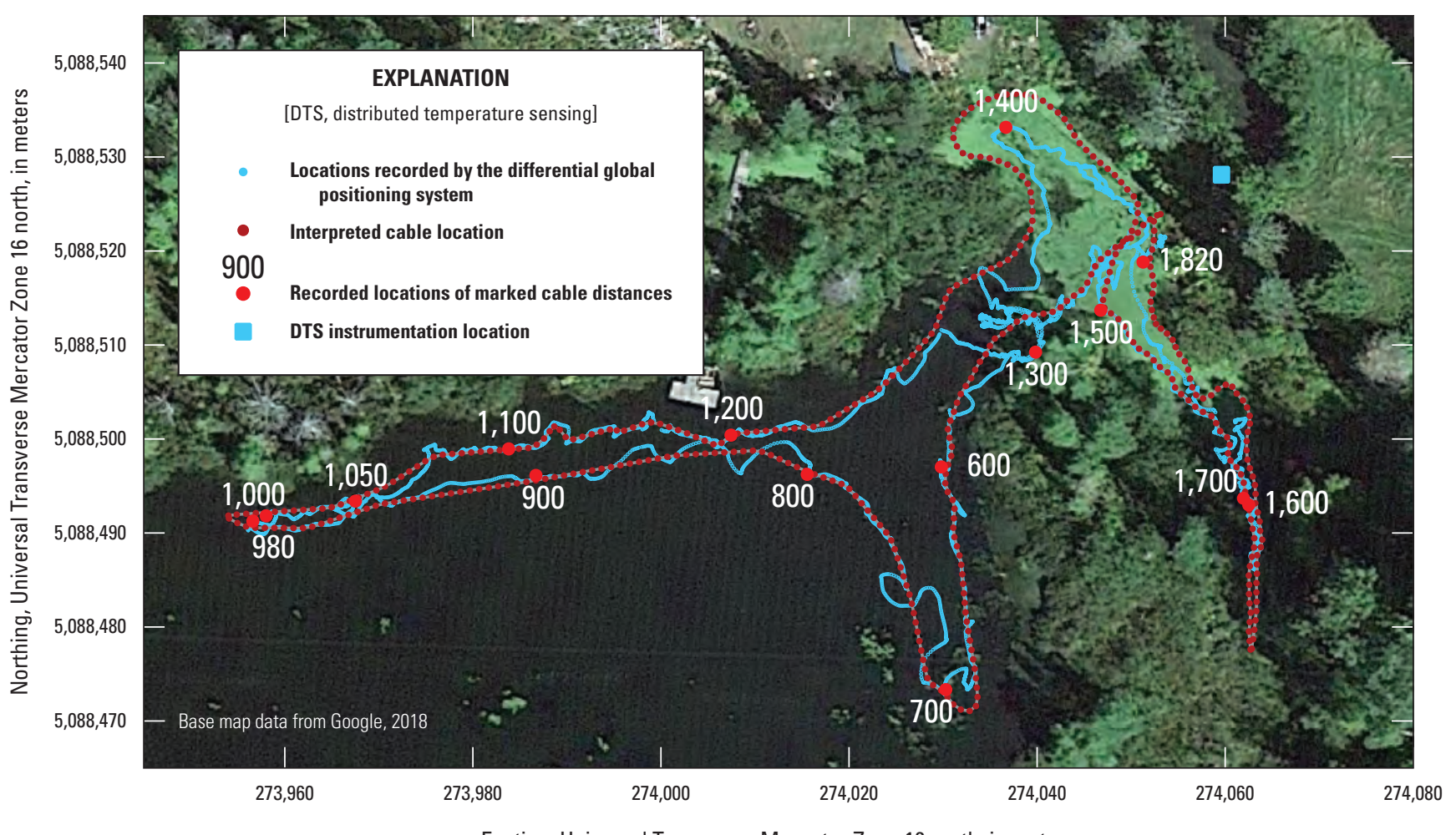

Figure 6. Interpreted cable location, with recorded boat stern position and recorded locations of cable distance markings.

distance-time plane is apparent. Only data through 10:45 a.m. on August 1, 2016, could be retrieved from the Oryx interrogator; the remaining data through August 3 were lost because of an instrument error. The spooled and calibration bath segments of the cable can be seen to the left of the 466-ft mark, where the cable enters the lake. Temperatures recorded in the lake (at the sediment-water interface) indicate a variation of more than $5{ }^{\circ} \mathrm{C}$ across the study area, with consistently cool zones interpreted to indicate preferential groundwater discharge. Horizontal banding visible across the lake temperatures (distances greater than $466 \mathrm{ft}$ ) in the early morning hours indicates apparent residual instrument noise that was not removed in the calibration. The source of this noise is unclear. Although no other independent measurements of temperature were collected along the cable away from the calibration baths, comparison of evening air temperatures recorded by the cable with records at nearby Lakeland Airport (fig. 1) provide additional confidence in the validity of the fiber temperatures (fig. 8).

Similar to Sebok and others (2013), the daily temperature range, standard deviation, and minimum temperatures were evaluated as possible indicators of groundwater discharge (figs. 9-11). As observed by Sebok and others (2013), the daily range and standard deviation have similar spatial patterns, but their interpretation is confounded by the effects of solar radiation and water depth. The daily minimum temperatures (fig. 11) are likely a more reliable indicator of groundwater discharge, because they represent early morning temperatures that are not affected by solar radiation. Average temperatures between 6 and 7 a.m. each day were ultimately selected to create a single map showing the thermal gradients across the site (fig. 12). Besides simplicity of presentation, averaging a 1-hour period for 5 days has the added advantage of further reducing instrument noise by averaging 150 temperature readings, instead of the 10 readings contained in a single set of daily minimums.

The daily minimum values consistently show cooler temperatures near shore, where greater amounts of groundwater discharge would be expected, but also some areas of cooler temperatures along the outside of the floating bog, to the west of the dock (fig. 11), which may indicate preferential groundwater discharge in these locations. The results are consistent with upward gradients measured by mini-piezometers in these areas, as well as upward fluxes inferred from vertical temperature profiles (Leaf and Haserodt, 2020). 


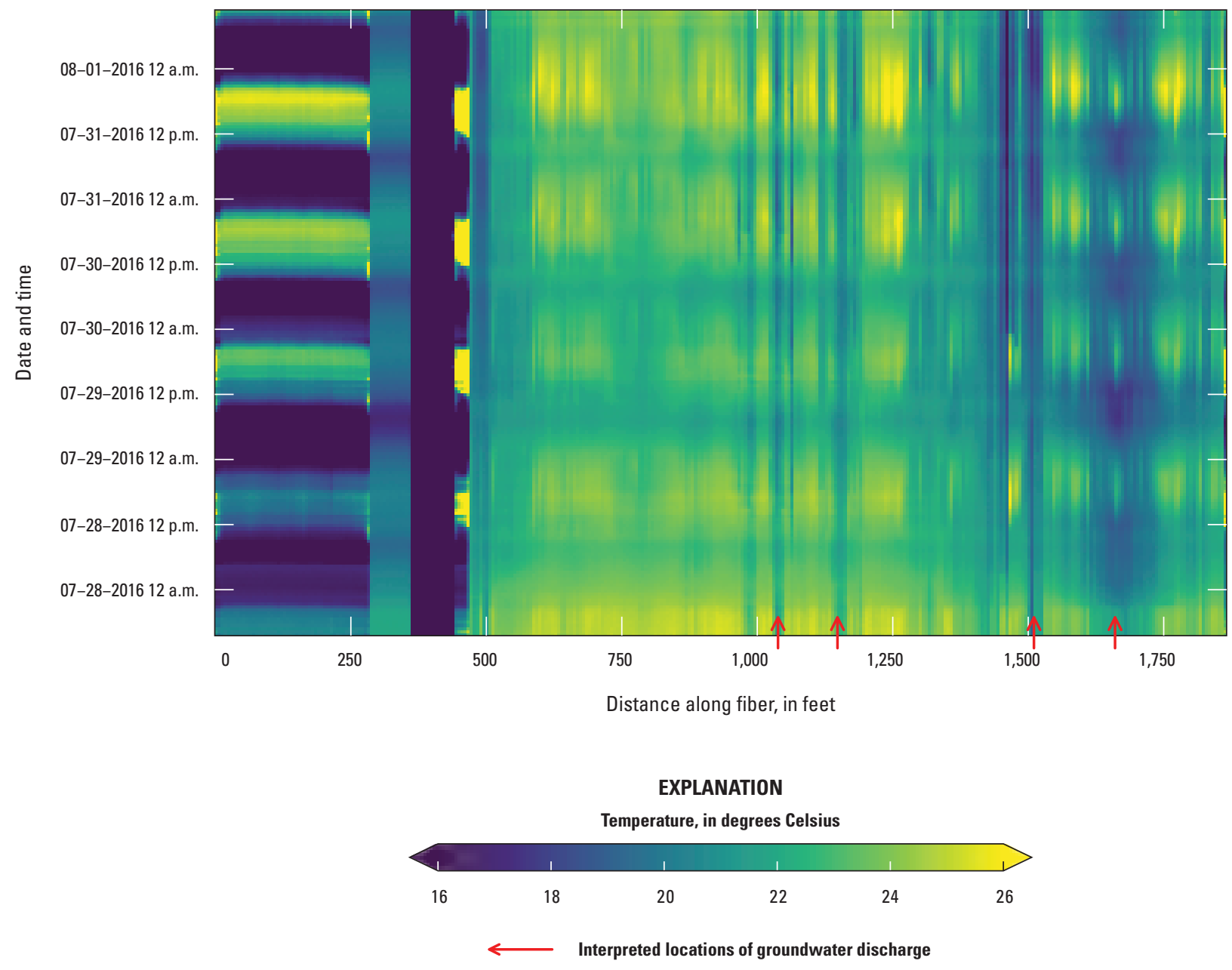

Figure 7. Time-distance image of the complete distributed temperature sensing dataset. From left to right, the first 300 feet of fiber, which remained spooled, are followed by 66-foot (20-meter) sections of fiber in the ambient and ice-water calibration baths. A short section of cable following the ice bath shows ambient air temperatures and the heating effects of solar radiation (temperatures greater than 25 degrees Celsius). The cable enters the lake at 466 feet. Areas that are consistently cool relative to most of the lake temperatures are interpreted to indicate groundwater discharge. 


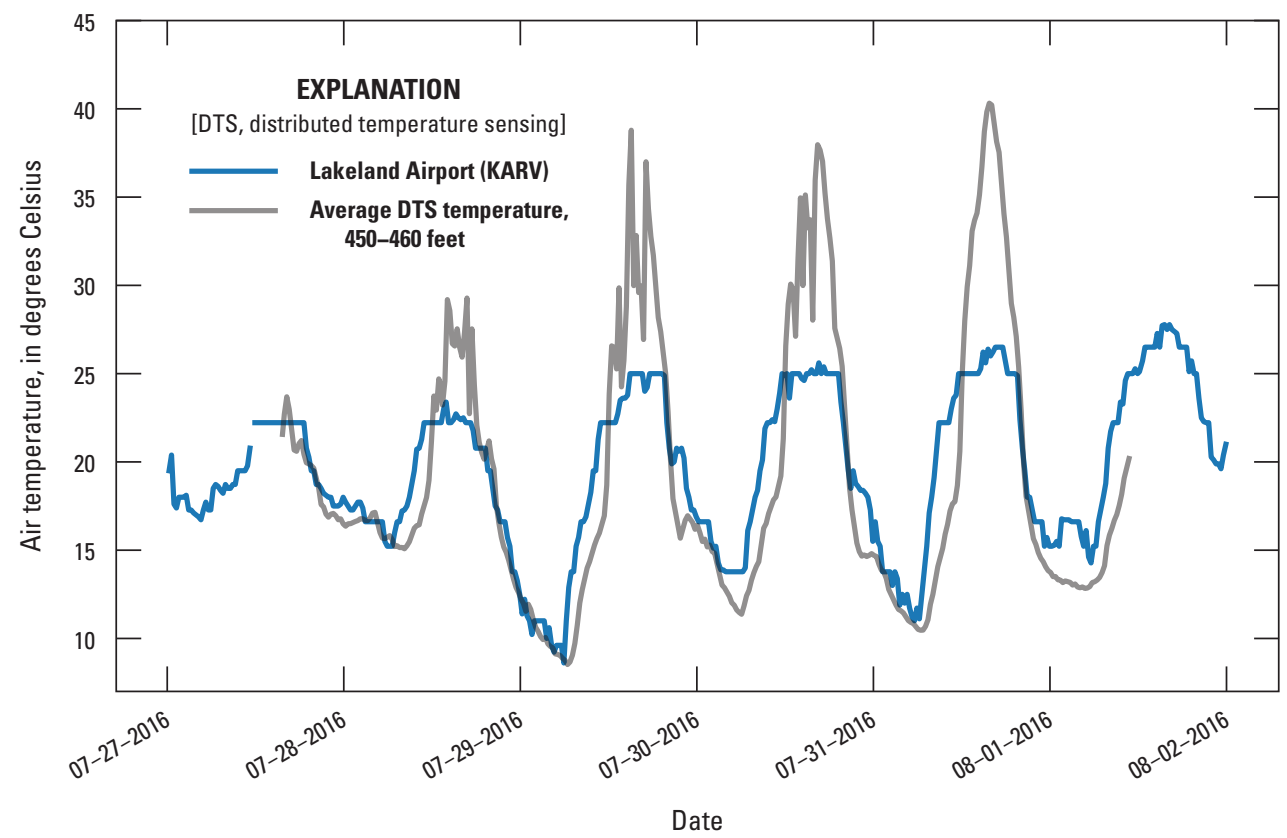

Figure 8. Air temperatures recorded by the section of fiber between the ice bath and lake compared to temperatures recorded at Lakeland Airport (National Oceanic and Atmospheric Administration, 2018), approximately 9 miles to the east. Apparent temperatures warmer than the airport temperatures show the heating effects of solar radiation on the cable. Good agreement in the evening and overnight temperatures provides some additional confidence in the accuracy of the calibrated fiber temperatures. The lag in morning temperatures recorded by the fiber is likely due to shading of the fiber in the eastern direction. 

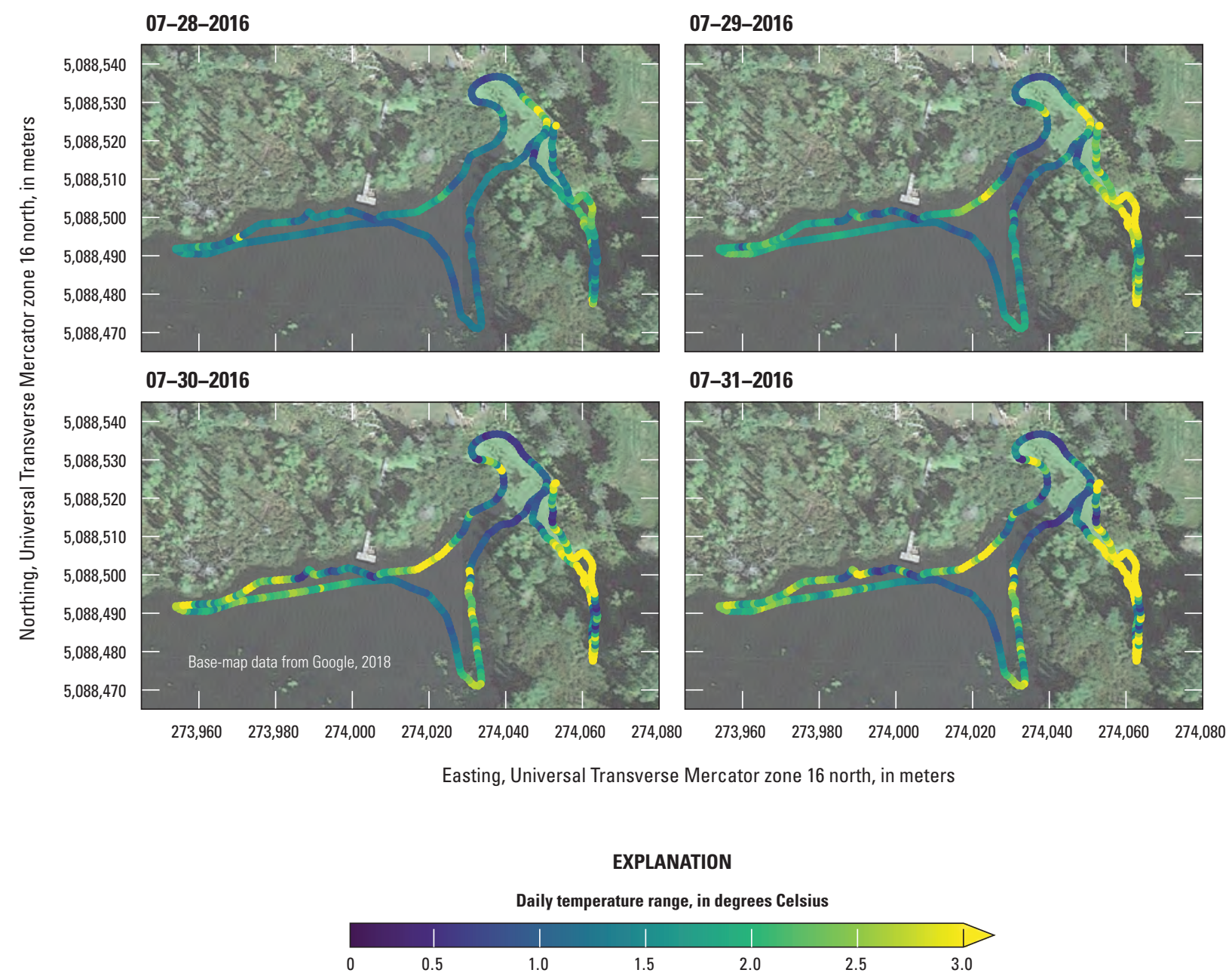

Figure 9. Daily temperature range (daily maximum temperature-daily minimum temperature) recorded by the distributed temperature sensing fiber. 


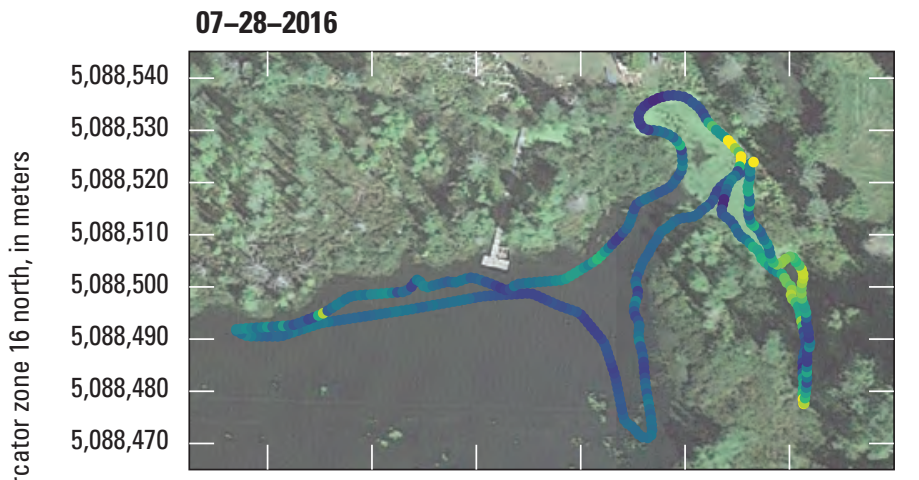

\section{7-29-2016}

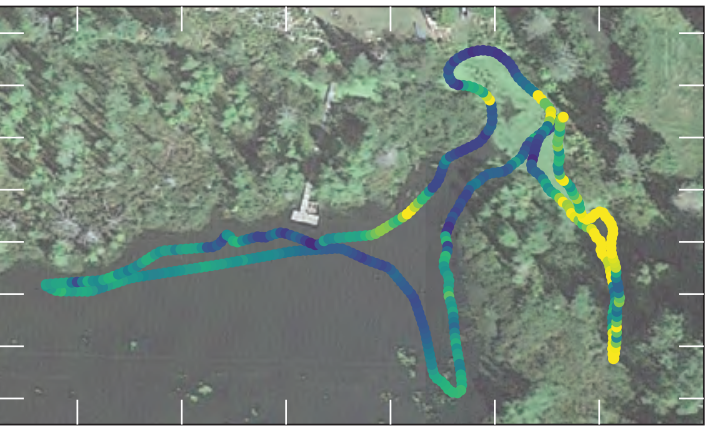

\section{7-30-2016 07-31-2016}

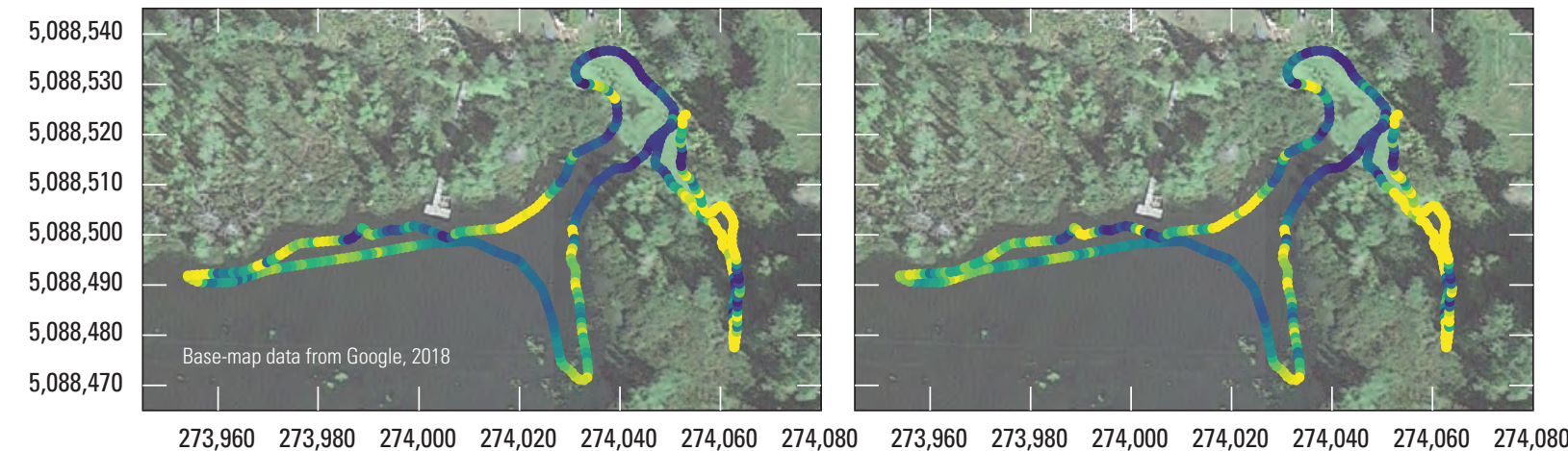

Easting, Universal Transverse Mercator zone 16 north, in meters

\section{EXPLANATION}

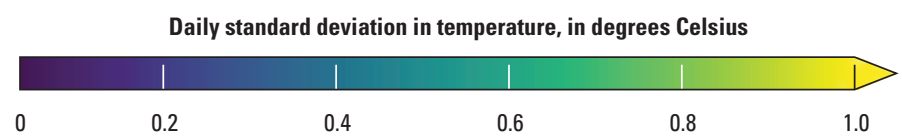

Figure 10. Daily standard deviation in temperatures recorded by the the distributed temperature sensing fiber. 

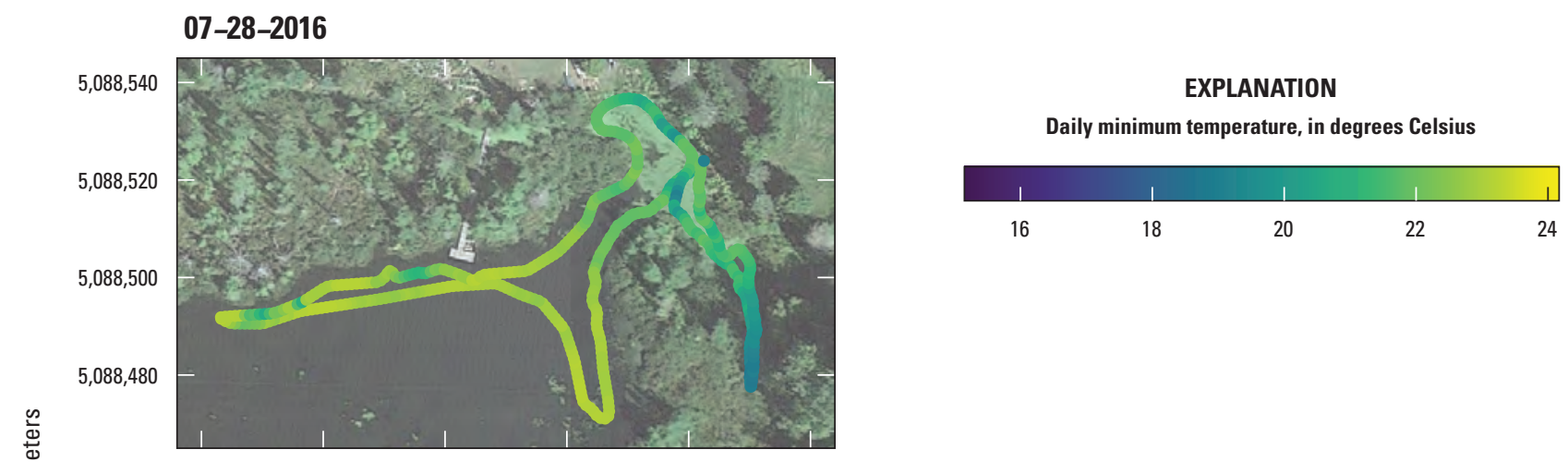

\section{7-29-2016}

07-30-2016
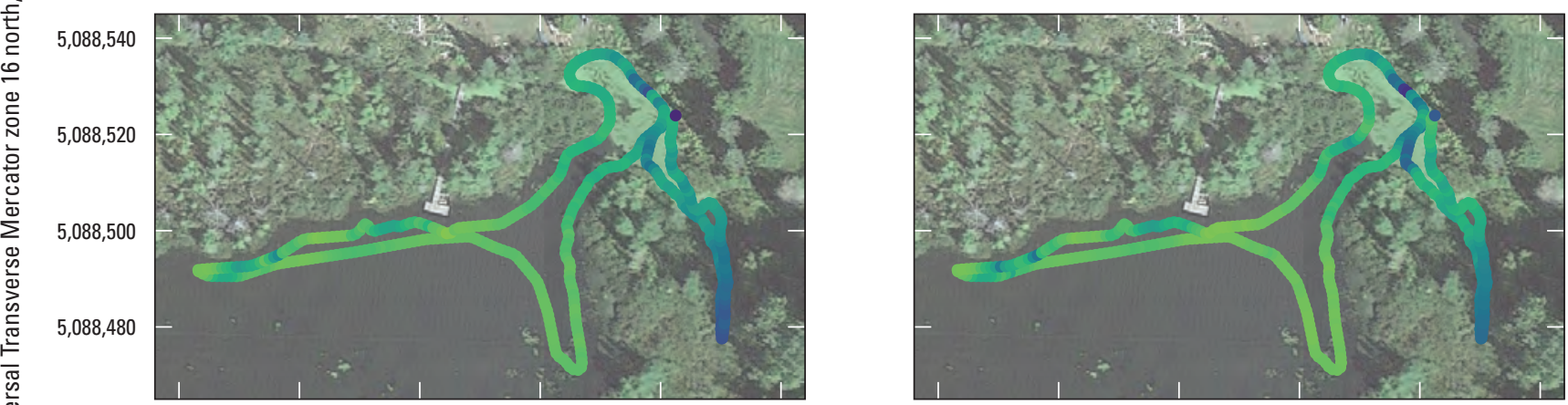

\section{7-31-2016}

$5,088,540$

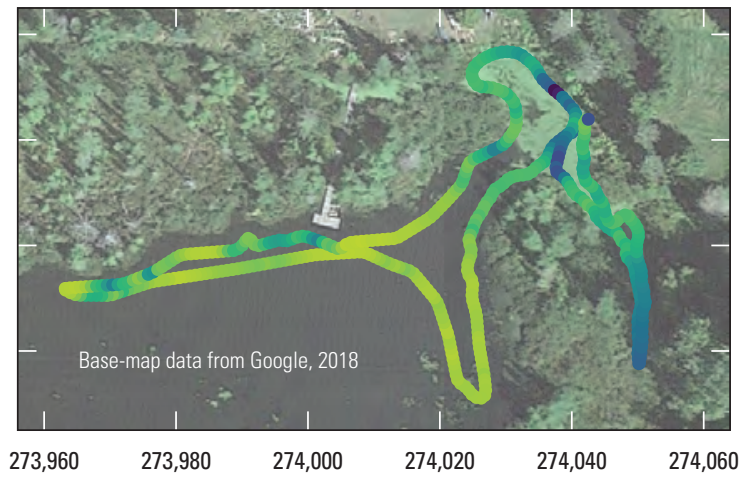

08-01-2016

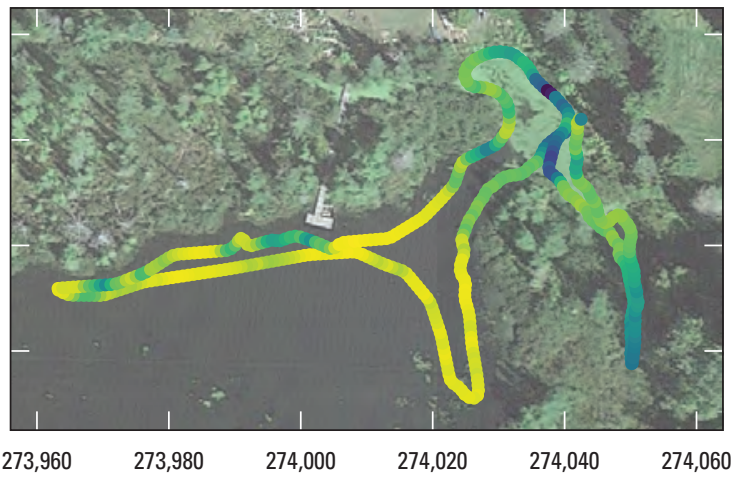

Easting, Universal transverse Mercator zone 16 north, in meters

Figure 11. Daily minimum temperatures recorded by the the distributed temperature sensing fiber. 


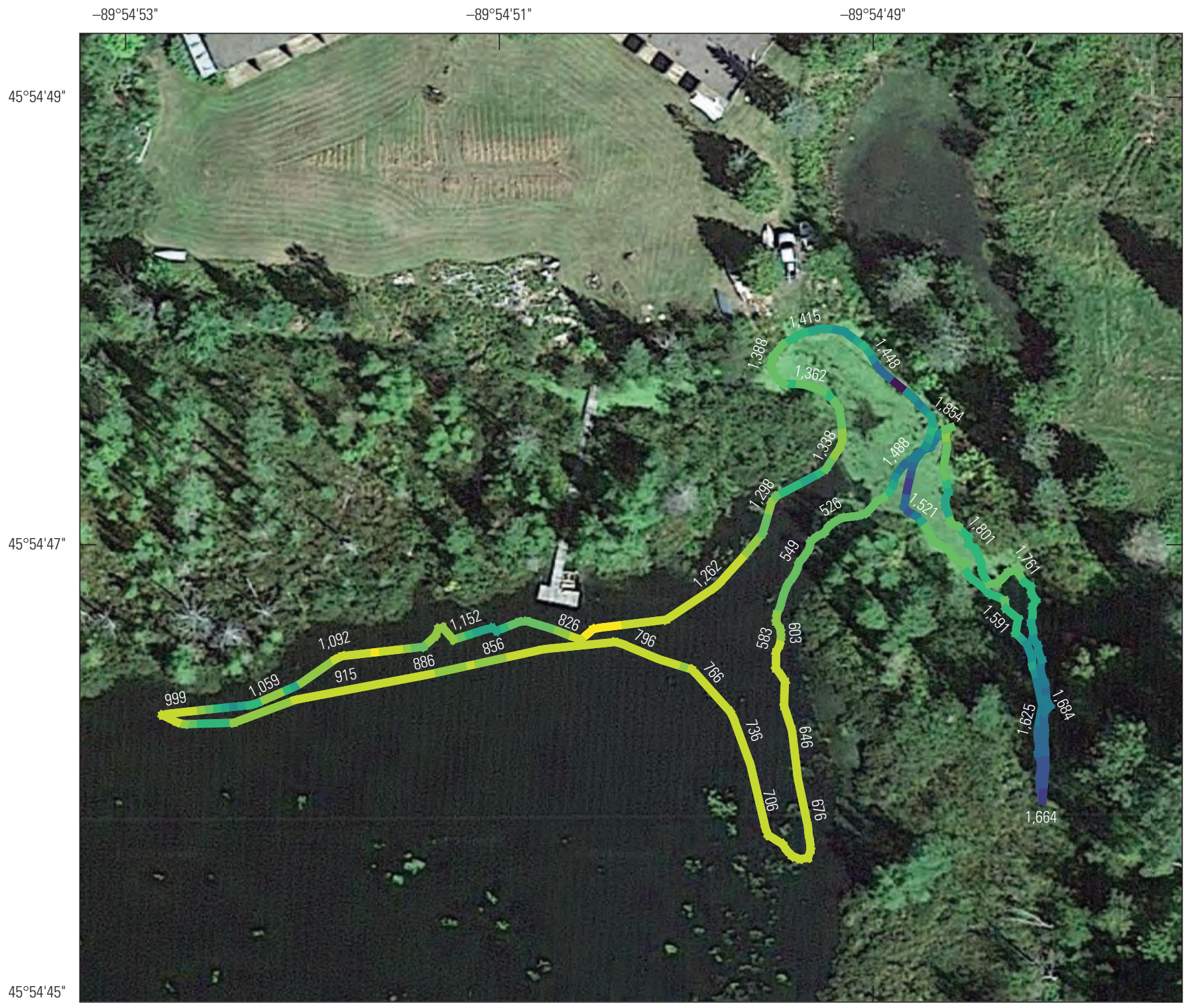

Base-map data from Google, 2015

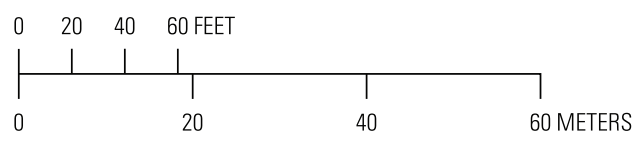

\section{EXPLANATION}

[DTS, distributed temperature sensing]

Early morning temperatures, in degrees Celsius, with labels of distance along the DTS cable, in feet.

\begin{tabular}{|l|l}
17.2 to 17.5 & 20.1 to 20.5 \\
17.6 to 18.0 & 20.6 to 21.0 \\
18.1 to 18.5 & 21.1 to 21.5 \\
18.6 to 19.0 & 21.6 to 22.0 \\
19.1 to 19.5 & 22.1 to 22.5 \\
\hline 19.6 to 20.0 & 22.6 to 22.9
\end{tabular}

Figure 12. Average temperatures between 6 and 7 a.m. (across the full the distributed temperature sensing dataset). 


\section{Summary and Conclusions}

Haskell Lake is a shallow, 89-acre drainage lake in the headwaters of the Squirrel River, on the Lac du Flambeau Reservation in northern Wisconsin. Historically, this lake was an important producer of wild rice for the Lac du Flambeau Band of Lake Superior Chippewa Indians (LDF Tribe); but, beginning in the late 1970s, the rice began to diminish and by the late 1990s, the lake no longer had harvestable stands. Restoring wild rice to Haskell Lake is a long-term priority for the LDF Tribe. A first step towards that effort is the cleanup of a petroleum-contamination plume in the shallow aquifer upgradient of the northern end of the lake. Knowledge of the downgradient extent of the plume and the locations where contaminated water is discharging to the lake is needed to inform cleanup efforts.

A cooperative study between the U.S. Geological Survey and the LDF Tribe was initiated to characterize the distribution of groundwater discharge to Haskell Lake in the areas downgradient of the contamination plume. A fiber optic distributed temperature sensing (DTS) survey of lakebed temperatures was completed at the north end of Haskell Lake from July 27 through August 3, 2016. Challenges during the investigation included data storage and power supply limitations, maintenance of calibration baths, accurate location of the cable in space, cable placement in weeds and soft sediment, the confounding effects of solar radiation, and contamination of the data by multiple sources of instrument noise. Instrument noise in the apparent fiber temperatures and the reference resistance temperature detector thermometers precluded automated calibration of the DTS data with the instrument control software, and underscores the importance of well-constructed calibration baths with collocated, independent measurements of temperature. DTS temperatures were ultimately computed from the raw Stokes/anti-Stokes data by solving the DTS calibration equation for two parameters that describe instrument noise. The cause of residual instrument noise remaining after the calibration is unclear, but good agreement between air temperatures recorded by the fiber and those recorded at a nearby airport provides some additional confidence in the DTS data. Additional independent measurements of temperature at other locations along the cable away from the calibration baths would be beneficial for future DTS surveys.

The results indicate a persistent variation in temperatures at the sediment-water interface of more than 5 degrees Celsius across the survey area, with consistently cool temperatures interpreted to indicate groundwater discharge. Similar to other studies, daily minimum temperatures provide the most meaningful indicator of groundwater discharge. Results of the study can be used to determine locations for collecting lakebed pore water samples to better define the extent of contamination discharging to the lake.

\section{References Cited}

Attig, J.W., 1985, Pleistocene geology of Vilas County: Wisconsin Geological and Natural History Survey Information Circular 50, 32 p., accessed September 26, 2017, at https:// wgnhs.uwex.edu/pubs/download_ic50/.

Conant, B., 2004, Delineating and quantifying groundwater discharge zones using streambed temperatures: Ground Water, v. 42, no. 2, p. 243-257.

Hausner, M.B., Suarez, F., Glander, K.E., van de Giesen, N., Selker, J.S., and Tyler, S.W., 2011, Calibrating single-ended fiber-optic raman spectra distributed temperature sensing data: Sensors (Basel), v. 11, no. 11, p. 10859-10879.

Jones, E., Oliphant, E., Peterson, P., and others, 2001, SciPyOpen source scientific tools for python: SciPy.org web page, accessed October 16, 2018, at https://www.scipy.org/.

Krabbenhoft, D.P., and Anderson, M.P., 1986, Use of a numerical ground-water flow model for hypothesis testing: Groundwater, v. 24, no. 1, p. 49-55. [Also available at https://doi.org/10.1111/j.1745-6584.1986.tb01458.x.]

Leaf, A.T., 2020, Distributed lakebed temperature data, Haskell Lake, Lac du Flambeau Reservation, Wisconsin, July 27-August 1, 2016: U.S. Geological Survey data release, https://doi.org/10.5066/P9X2OHNX.

Leaf, A.T. and Haserodt, M.J., 2020, Hydrology of Haskell Lake and investigation of a groundwater contamination plume, Lac du Flambeau Reservation, WI: U.S. Geological Survey Scientific Investigations Report 2020-5024, 79 p., https://doi.org/10.3133/sir20205024.

Lowry, C., Walker, J., Hunt, R., and Anderson, M., 2007, Identifying spatial variability of groundwater discharge in a wetland stream using a distributed temperature sensor: Water Resources Research, v. 43, no. 10, p. 1-9.

McBride, M.S., and Pfannkuch, H.O., 1975, Distribution of seepage within lakebed: Journal of Research of the U.S. Geological Survey, v. 3, no. 5, p. 505-512.

McDaniel, A., Tinjum, J.M., Hart, D.J., and Fratta, D., 2018, Dynamic calibration for permanent distributed temperature sensing networks: IEEE Sensors Journal, v. 18, no. 6, p. 2342-2352.

National Oceanic and Atmospheric Administration, 2018. Local climatological data for Lakeland Noble Lee Memorial Field Airport, WI station WBAN:04865: National Oceanic and Atmospheric Administration web page, accessed May 29, 2018, at https://www.ncdc.noaa.gov/cdo-web/datasets/ LCD/stations/WBAN:04865/detail. 
Rosenberry, D.O., LaBaugh, J.W., and Hunt, R.J., 2008, Use of monitoring wells, portable piezometers, and seepage meters to quantify flow between surface water and ground water, in Rosenberry, D.O., and LaBaugh, J.W., eds., Field techniques for estimating water fluxes between surface water and ground water: U.S. Geological Survey Techniques and Methods, book 4, chap. D2, p. 39-70.

Sebok, E., Duque, C., Kazmierczak, J., Engesgaard, P., Nilsson, B., Karan, S., and Frandsen, M., 2013, High-resolution distributed temperature sensing to detect seasonal groundwater discharge into Lake Væng, Denmark: Water Resources Research, v. 49, no. 9, p. 5355-5368.

Sensornet, 2007, Oryx DTS user manual (ver. 2): London, Sensornet, Ltd., 95 p.

Tyler, S.W., Selker, J.S., Hausner, M.B., Hatch, C.E., Torgersen, T., Thodal, C.E., and Schladow, S.G., 2009, Environmental temperature sensing using Raman spectra DTS fiber-optic methods: Water Resources Research, v. 45, no. 4.
U.S. Geological Survey, 2004, USGS small-scale datasetCities and towns of the United States 200402 shapefile: U.S. Geological Survey digital data, accessed August 11, 2004, at http://nationalatlas.gov/atlasftp.html.

U.S. Geological Survey, 2013, National elevation dataset: U.S. Geological Survey digital data, accessed December 20, 2017, at https://nationalmap.gov.

van de Giesen, N., Steele-Dunne, S.C., Jansen, J., Hoes, O., Hausner, M.B., Tyler, S., and Selker, J., 2012, Doubleended calibration of fiber-optic Raman spectra distributed temperature sensing data: Sensors (Basel), v. 12, no. 5, p. 5471-5485.

Wisconsin Department of Natural Resources, 2015, WDNR 24K Hydro Geodatabase: Wisconsin Department of Natural Resources digital data, 1:24,000, accessed June 8, 2016, at ftp://dnrftp01.wi.gov/geodata.
For more information about this publication, contact:

Director, USGS Upper Midwest Water Science Center

8505 Research Way

Middleton, WI 53562

608-828-9901

For additional information, visit: https://www.usgs.gov/centers/umidwater

Publishing support provided by the

Madison and Rolla Publishing Service Centers 




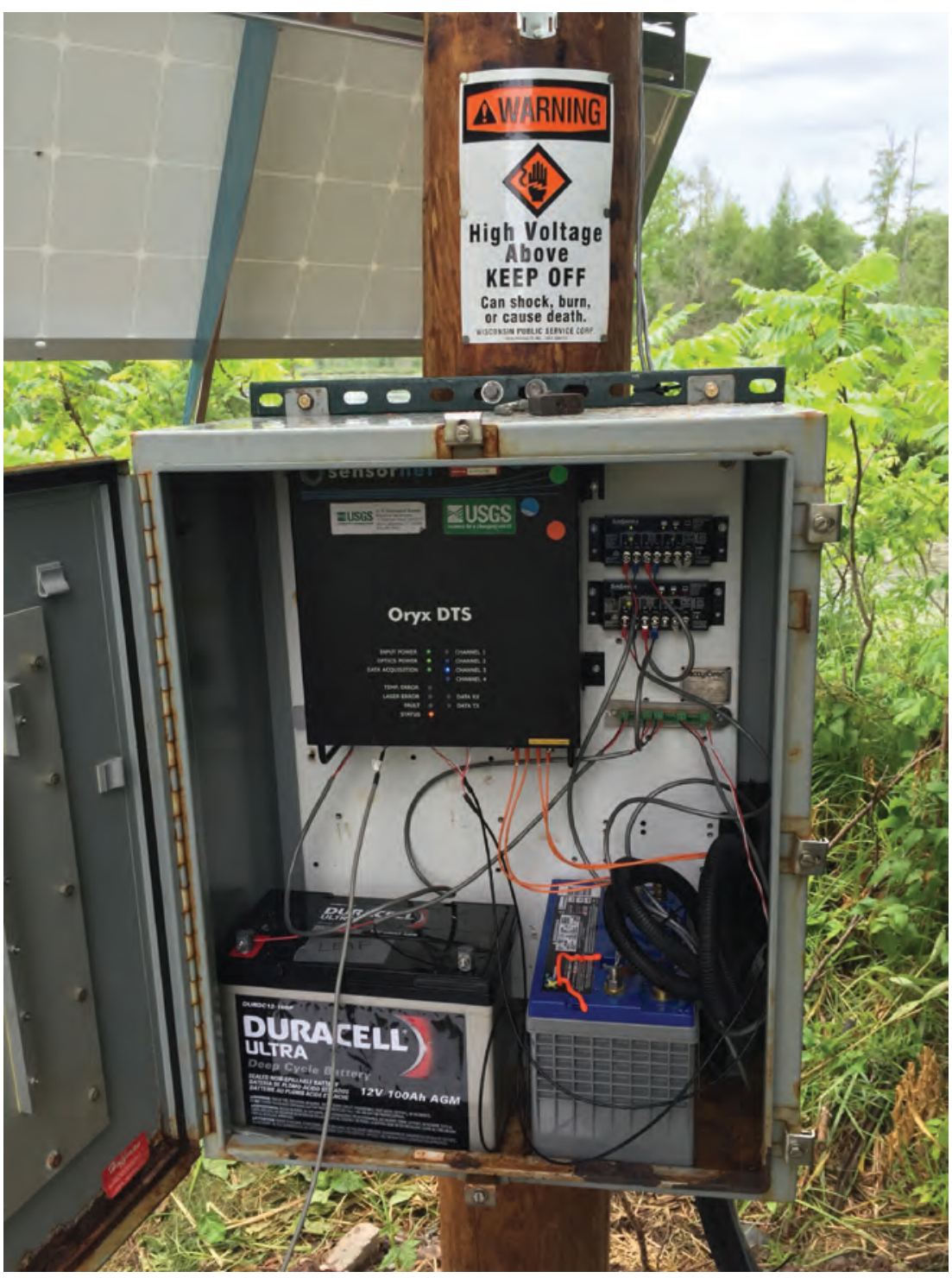

